\title{
The Psychological Impact of the COVID-19 Pandemic on Oral Health Care Workers and its Impact on Their Willingness to Work During this Pandemic
}

\author{
Farooq Ahmad Chaudhary ${ }^{1}$, Basaruddin Ahmad², Madiha Gul ${ }^{3}$, \\ Aamir Rafiq ${ }^{3}$, Danial Qasim Butt 3 , Misbah Rehman, Paras Ahmad² \\ ${ }^{1}$ School of Dentistry, Shaheed Zulfiqar Ali Bhutto Medical University, Islamabad, Pakistan \\ ${ }^{2}$ School of Dental Sciences, Universiti Sains Malaysia, Kubang Kerian, Malaysia, ${ }^{3}$ Dental \\ College, HITEC Institute of Medical Sciences, Taxila, Pakistan, ${ }^{4}$ Islamic International \\ Dental College, Riphah international university, Islamabad, Pakistan
}

\begin{abstract}
This study was aimed to investigate the relationship between the psychological status of oral health care workers (OHCWs) and the willingness to treat a patient during the COVID-19 pandemic. This cross-sectional study was carried out on oral health care workers at ten different dental hospitals in Pakistan from March to July 2020. Information on the socio-demographic status, and willingness to report for duty and treat patients during the COVID-19 pandemic were assessed using a self-administered questionnaire. The psychological impact of the COVID-19 pandemic was assessed using the Urdu version of the Generalized Anxiety Disorder Scale and Impact of Events Scale. Simple and multiple linear regression tests were used for analysis. A total of $392 \mathrm{OHCWs}$ participated in this study and $25 \%$ of them had moderate to severe anxiety levels and only $14 \%$ had post-traumatic stress disorder. About 26\% of the OHCWs were willing to work and treat patients during the COVID-19 pandemic and they had lower anxiety and stress scores. Greater anxiety and stress were associated with participants who were older, female, single, married, living with family and friends. The adjusted coefficients of GAD and IES scores were greater in participants who were not willing and unsure to work compared to their colleagues who were willing. The OHCWs are anxious and stressed because of the COVID-19 outbreak and that affects the perception of whether they should work and treat patients during the pandemic.
\end{abstract}

Keywords: anxiety; COVID-19; oral health care worker; psychological impact; willingness

Copyright @ 2021 KBCSM, Zagreb

e-mail: apr.kbcsm@gmail.com•www.http://apr.kbcsm.hr

\section{Introduction}

By the end of 2019, the novel coronavirus (COVID-19) outbreak in Wuhan, China made global headlines and continues to spread glob-

\section{Correspondence to:}

Farooq Ahmad Chaudhary, PhD, MDPH, MPH

Department of Community Dentistry, School of

Dentistry, Shaheed Zulfiqar Ali Bhutto Medical

University, Islamabad, Pakistan

Phone: + 92 3325-5606-44

E-mail: chaudhary4@hotmail.com ally at speed [1]. To date, the World Health Organization (WHO) estimated that the reproduction number and global mortality rate stand at 1.4-5.5 and 3.4\%, respectively [2]. The WHO declared the COVID-19 crisis as a "Public Health Emergency of International Concern" on Jan. 31, 2020, and subsequently, a pandemic on March 11, 2020 [3]. 
This large-scale public health event imposes enormous pressure on the governments and burdens the health care facilities, healthcare providers, families, and individuals in general [4]. The spread of information about Covid-19 through the news coverage, social media, and the internet are overwhelming and instill fear of infection and death, and rouse the emotional and socio-psychological vigilance among the public, including the health care providers who routinely work with Covid-19 patients $[5,6]$.

Covid-19 has disrupted hospital operations with the closure of outpatient clinics, cancellation of surgery and non-emergency appointments, restriction of visitation privileges, limitation of entry into the buildings to essential staff with strict screening protocols [7]. The use of masks, gloves, and gowns is mandatory by hospital staff who are attending to their patients, and healthcare workers (HCWs) are recommended to limit the number of contact outside work [8,9].

Hospitals in many countries are overwhelmed by the number of Covid-19 cases that outstripped the capacity of intensive care units, causing a shortage of beds, ventilators, and medications, and attending doctors and nurses [6, 10]. More than 90,000 health care workers were believed to be infected with COVID-19 according to the International Council of Nurses (ICN), amid reports of ongoing shortages of PPE [11]. Similarly, more than 3,000 health care workers in Wuhan, China were infected with COVID-19 at an early stage (before and in January of 2020) [12,13].

The risk of hospital infection during a pandemic is a major concern among the professional health care providers who are divided between personal safety and that of the family and friends, and the responsibility to serve the need of the people $[9,12]$. This sense of fear and responsibility can cause distress and influence work behavior to an extent. For example, it has been reported that hospital workers are less willing to report for duty for fear of getting infected during the SARS outbreak $[14,15]$.

Hospital infection can also affect oral health care workers (OHCWs) in dental clinics. There is a risk of transmitting the COVID-19 to the dentist and dental nurses during the dental procedure such as dental scaling and restoring a carious tooth $[16,17]$. Viral transmission during dental practice has been reported during the Ebola, MERS-CoV, H1N1, and H5N1 outbreaks [18,19]. Thus far, earlier reports on the psychological impact, and willingness to report for duty and provide care during a pandemic only involved the medical health care workers [20,21]; little is understood about the oral health care workers despite facing similar challenges and occupational hazards. Hence, this study was aimed to investigate the relationship between the psychological status of OHCWs and the willingness to treat a patient during the COVID-19 pandemic.

\section{Subjects and Methods}

An investigating survey was carried out on dentists, dental assistants, and hygienists at the dental hospitals in different regions (KPK, Pun$\mathrm{jab}$, Sindh) and the administrative capital of Pakistan (Islamabad) from April to July 2020. These OHCWs were selected because of the close and direct contact between them and the patients during dental treatment procedures. Participation in the study was voluntary and ethical approval was taken from the University (Reference no. F.2514C/2020/ERC/IMS). The respondents were identified and contacted by an appointed staff at the respective institutions. They were briefly explained about the study and provided with a set of documents that consists of a letter that further explains the purpose of the research, a consent form, and a research questionnaire. The latter collected the information on age group, sex, marital status, job description, place of work, and place of living. The willingness to report for duty and treat patients during the COVID-19 pandemic was as- 
sessed by asking the respondents "Are you willing to continue working and treat patients during COVID-19 pandemic" and the response was recorded as 'Yes', 'No' and 'Unsure'. The Urdu version of the Generalized Anxiety Disorder Scale (GAD-7) and the Impact of Events Scale (IES) [22,23] were used to assess the psychological impact of the COVID-19 pandemic on the respondents. The GAD-7 has 7 -items to assess the symptoms of anxiety on a four-point Likert scale, from 0 (not at all) to 3 (almost every day). The final score was obtained by the simple addition of the responses ranges from 0 to 21 and a greater value indicates more severe anxiety. It was also categorized into four severity levels: minimal (0-4), mild (5-9), moderate (1014), and severe (14-20) for descriptive purposes [22]. The Urdu version of GAD-7 has been validated and shown to have excellent internal constancy (Cronbach's alpha 0.92) [22]. The IES is a 15-item instrument to assess posttraumatic stress disorder (PTSD) caused by traumatic events [8]. The revised Urdu version of IES-R used in this study contains 7 additional items that cover three clusters of PTSD symptoms; intrusion, avoidance, and hyperarousal [23]. The response of each item is scored on a five-point Likert scale, from 0 (not at all) to 4 (extremely). The final score ranges from 0 to 88 . A threshold score $>20$ indicates that the individual has PTSD [24].

\section{Statistical analysis}

Descriptive analyses were carried out to summarize the sample and the psychological parameters were described by the willingness to treat patients. The relationship between sociodemographic factors and psychological measures, and willingness to work was examined using the simple and multiple linear regression with the 'not willing to work' category set as the reference group. Adjusted coefficients were obtained using the stepwise method with $\mathrm{p}_{\text {inclusion }}<0.05$ and $\mathrm{p}_{\text {remove }}>0.1$. The significance level of 5\% was considered for all the analyses which were performed using IBM SPSS software version 26.0.

Psychological Impact of COVID-19 on Oral Health Care Workers

\section{Results}

The questionnaires were distributed to 401 subjects but only $392(97.7 \%)$ participants completed all the questions. The majority of the sample was between 20 - 39 years-old $(62.2 \%)$, male $(55 \%)$, married $(76.8 \%)$, and a dentist (65\%) (Table 1). There were slightly greater percentages of participants working in government sector hospitals (52.3\%), and most of them lived with their family and friends $(88 \%)$.

The summary statistics of the psychological measures are presented in Table 2. About $25 \%$ of the participants had moderate to severe anxiety levels $(82.4 \%$ ) and only $14 \% \mathrm{had}$ post-traumatic stress disorder. About 26\% of the respondents were willing to work and treating patients, (Table 2) and they had lower anxiety and stress scores than those who were not willing and unsure (Table 2).

Greater anxiety and stress were associated with participants who were older, female, single, married, living with family and friends (Table 3). The analysis showed that the adjusted coefficients of GAD7 and IES scores were greater in participants who were not willing and unsure to work compared to their colleagues who were willing; and no difference in the adjusted coefficients of GAD and IES scores between the former two groups (Table 4).

\section{Discussion}

This study assessed the psychological status of OHCWs whose work involves direct contact with a patient who could be a potential COVID-19 positive and examined its association with the willingness to work and treat patients during the pandemic. The results suggest that the majority of the OHCWs $(82.4 \%)$ are anxious and stressed because of the COVID-19 pandemic. This is similar to the nondentist HCW in earlier reports [25,26]. The analysis found associations between anxiety 
Table 1. The summary statistics of the participants, anxiety levels, stress, and willingness to work $(\mathrm{N}=392)$.

\begin{tabular}{lr}
\hline Characteristics & Number (\%) \\
\hline Age & $124(31.6)$ \\
$20-29$ & $120(30.6)$ \\
$30-39$ & $98(25.0)$ \\
$40-49$ & $50(12.8)$ \\
$50-60$ & \\
Gender & \\
Male & $177(45.2)$ \\
Female & $215(54.8)$ \\
& \\
Marital status & \\
Single & $77(19.6)$ \\
Married & $301(76.8)$ \\
Divorced & $12(3.1)$ \\
Widowed & $2(0.5)$ \\
& \\
Job description & \\
Dentist & $254(64.8)$ \\
Dental Assistant/hygienist & $138(35.2)$ \\
Place of work & \\
Government/public sector & $205(52.3)$ \\
Private sector & $187(47.7)$ \\
\hline
\end{tabular}

Table 1. (Continued)

\begin{tabular}{lr}
\hline Characteristics & Number (\%) \\
\hline Staying with & \\
Family/friend & $344(87.8)$ \\
Alone & $48(12.2)$ \\
& \\
GAD7, mean (sd) & $2.13(0.68)$ \\
Normal & $57(14.5)$ \\
Mild & $239(61.0)$ \\
Moderate & $84(21.4)$ \\
Severe & $12(3.1)$ \\
& \\
IES, mean (sd) & $25.45(16.8)$ \\
No PTSD & $337(86.0)$ \\
Yes PTSD & $55(14.0)$ \\
& \\
Willingness to work & \\
Yes & $103(26.3)$ \\
No & $204(52.0)$ \\
Not sure & $85(21.7)$ \\
& \\
\end{tabular}

Table 2. The mean (sd) of anxiety and stress scores by the willingness to work and treat patients during the Covid-19 pandemic.

\begin{tabular}{lcccc}
\hline & \multicolumn{4}{c}{ Willingness to treat } \\
Mean (sd)
\end{tabular}

GAD-7 - Generalized Anxiety Disorder Scale; IES - Impact of Events Scale 
Table 3. The regression coefficient of the association between and the socio-demographic, anxiety, and stress factors and willingness to work and treat patients during the Covid-19 pandemic

\begin{tabular}{|c|c|c|}
\hline & $\begin{array}{r}\text { GAD } \\
\text { Coefficient (se) }\end{array}$ & $\begin{array}{r}\text { IES } \\
\text { Coefficient (se) }\end{array}$ \\
\hline Characteristics & $\mathrm{p}$ & $\mathrm{p}$ \\
\hline Age & $\begin{array}{r}1.8(0.15) \\
0.001\end{array}$ & $\begin{array}{r}5.0(0.80) \\
0.001\end{array}$ \\
\hline Gender & $\begin{array}{r}1.3(0.35) \\
0.001\end{array}$ & $\begin{array}{r}4.4(1.70) \\
0.01\end{array}$ \\
\hline Marital status & $\begin{array}{r}2.0(0.36) \\
0.001\end{array}$ & $\begin{array}{r}5.8(1.77) \\
0.001\end{array}$ \\
\hline $\begin{array}{l}\text { Single } \\
\text { Divorced } \\
\text { Widowed } \\
\text { Married }\end{array}$ & $\begin{array}{r}-2.8(0.43)(<0.001)^{*} \\
-0.9(1.04)(0.4) \\
4.5(2.50)(0.1) \\
2.5(0.40)(<0.001)^{*}\end{array}$ & $\begin{array}{r}-7.3(2.1)(0.001) \\
-2.3(4.94)(0.6) \\
22.2(11.9)(0.1) \\
6.2(2.0)(0.002)\end{array}$ \\
\hline Job description & $\begin{array}{r}-0.3(0.37) \\
0.3\end{array}$ & $\begin{array}{r}-2.8(1.78) \\
0.1\end{array}$ \\
\hline Place of work & $\begin{array}{r}-0.3(0.35) \\
0.3\end{array}$ & $\begin{array}{r}-3.0(1.70) \\
0.1\end{array}$ \\
\hline $\begin{array}{l}\text { Staying with family / friends } \\
\text { Willingness }\end{array}$ & $\begin{array}{r}-2.6(0.53) \\
0.001\end{array}$ & $\begin{array}{r}-7.3(2.57) \\
0.005\end{array}$ \\
\hline Yes & $\begin{array}{r}-4.0(0.35) \\
0.001\end{array}$ & $\begin{array}{r}-8.5(1.89) \\
0.001\end{array}$ \\
\hline No & $\begin{array}{r}2.2(0.34) \\
0.001\end{array}$ & $\begin{array}{r}3.2(1.70) \\
0.06\end{array}$ \\
\hline Not sure & $\begin{array}{r}1.3(0.43) \\
0.003\end{array}$ & $\begin{array}{r}5.0(2.05) \\
0.02\end{array}$ \\
\hline
\end{tabular}

GAD-7 - Generalized Anxiety Disorder Scale; IES - Impact of Events Scale ${ }^{*} \mathrm{p}<0.001$

and stress due to COVID-19, and the willingness to work during the pandemic; participants who are unwilling or unsure are more anxious and stressed than those who are willing. The findings suggest that although they understand the duties, responsibilities, ethics, and preventive measures needed in matters relating to the treatment of individuals with blood or air-borne infectious disease, they are still worried about the on-going pandemic.

About half of the respondents in this study $(52 \%)$ are not willing to work and treat dental patients in the hospital during the COVID-19 pandemic. A similar reaction among the $\mathrm{HCW}$ was reported during the severe acute respiratory syndrome (SARS) epidemic in 2003; about 
Table 4. The adjusted regression coefficient for the association between anxiety and stress, and willingness to work and treat patients during Covid-19 pandemic

\begin{tabular}{lrr}
\hline & GAD & IES \\
Characteristics & Coefficient (se) & Coefficient (se) \\
\hline
\end{tabular}

Willingness adjusted (reference: Yes)

No, coefficient $(95 \% \mathrm{CI})$

Not sure, coefficient $(95 \% \mathrm{CI})$

\begin{tabular}{rr}
$2.6(1.96,3.26)$ & $5.0(1.13,8.91)$ \\
$(<0.001)$ & 0.01 \\
\hline
\end{tabular}

GAD-7 - Generalized Anxiety Disorder Scale; IES - Impact of Events Scale

a adjusted for age and gender, ${ }^{b}$ adjusted for age, ${ }^{*} \mathrm{p}<0.001$

$43 \%$ of nurses in Taiwan were not willing or considering not to care for patients infected with Avian influenza [27]. In another report, about $25 \%$ of nurses considered looking for another job or resigning because of the risk of infection[28]. The health-care professionals in Germany find it acceptable to abandon their duties in order to protect themselves and their families during the Avian influenza pandemic and, in the USA, almost half of the local health department workers indicated that they would not report for duty[29,30]. The recent COVID-19 pandemic, $16 \%$ of nurses at the medical center in North Gyeongsang Province in China had resigned because of fear of getting infected and spreading it to their family, and overwork during the outbreak [31]. The perceived risk of fatality linked to the pandemic is another important reason for leaving the job or not reporting for work among the HCW [9]. Studies suggested that the social distancing orders, which require the OHCWs to stay home, being in isolation, and cut out of interpersonal interaction and communication increases the anxiety level over time $[32,33]$. Anxiety intensifies as the perception about the risk of infec- tion and mortality increases, which is heightened by the mass media COVID-19 highlights [34]. Conditions are made worse by the potential infection at the workplace due to personal protective equipment shortage and lack of medical supplies at health care facilities, insufficient lab testing and treatment opportunities, prolonged working hours, and other developing concerns [9,34].

Similar to the report on HCWs in China, the female respondents are more affected than men, possibly related to the responsibilities to their children and other family members [35]. This is observed in the current study where higher anxiety and stress are observed in married respondents and those living with families and friends. The Covid-19 scare also affects the people around the HCWs in the past. The family members are reported to worry about getting the infection from the health care workers [9]. Also reported, taxi drivers had refused to accept HCWs as passengers and fellow train commuters kept a distance from people in hospital uniforms. Some HCW reported that their family members are also treated in the same manner [36]. Fortunately, 
the prejudice against the HCWs in the current pandemic has been addressed effectively. Concerted effort using all forms of media to highlight the work commitment and dedication of HCW had changed the public opinion from fear to gratitude. It is probable that the respondents aged 40 - 60 years in this study are more anxious because the mortality rate of COVID-19 is greater in the older population. This differs from the previous reports where anxiety in HCWs aged $>50$ years during an outbreak is linked to direct contact with a death case, exhaustion due to prolonged work hours, and lack of PPE [37].

To help reduce anxiety and stress at the workplace, oral healthcare facilities must develop effective strategies to overcome the concern of the OHCWs. Psychological screening and/or walk-in consultation can be offered to identify those with potential problems and followed by the appropriate address of the issues [38-40]. In the current condition, many noncritical dental treatments had been postponed because of the great risk of transmission during the dental procedure and but there are emergency cases that needed attention; these cases can be attended to but with strict precaution.

To the best of our knowledge, this study is the first to report the psychological impact of the COVID-19 pandemic on oral health care providers and its relationship with willingness to work, hence a reference for responsible agencies to understand the impact of an outbreak on oral health care professionals. Many factors contribute to the difference in the psychological response to COVID-19 in OHCWs compared to HCWs. Firstly, HCWs workload increases substantially during this pandemic, on the other hand, mostly OHCWs did not perform any non-emergency procedures, and reduce their work hours. Secondly, HCWs working with repeatedly changing protocols, treating deteriorating critical patients, and taking hard decisions regarding treatment continuation due to limited resources affects psychological conditions more than in OHCWs [41]. Lastly, studies have reported that OHCWs were facing financial problems due to limited and lowered working hours that can cause pandemic imposed financial distress [42].

There are a few limitations to this study. The cross-sectional study design with selfadministered questionnaires can have recalled, framing, rating bias and could induce social desirability resulted in not reporting the actual behavior but the behaviors that would be desired by the society. The findings of this study on OHCWs cannot be generalized to other OHCWs working in different regions with ever-changing responses to the COVID-19 pandemic. More studies in different cultures and regions are still needed to understand the impact of the pandemic on OHCWs worldwide along with the strategies and effort to overcome the issue.

The Current Study Found That Oral Health Care Workers Are Anxious And Stressed Because Of The COVID-19 Outbreak And That Affects The Perception Of Whether They Should Work And Treat Patients During The Pandemic. There Is A Need For An Effective Intervention Program To Improve The Psychological Impact Of COVID-19 Consequences On OHCW.

\section{Acknowledgements}

None.

\section{Conflict of Interest}

The authors declare that they have no conflict of interest. 


\section{References}

1. Zhu H, Wei L, Niu P. The novel coronavirus outbreak in Wuhan, China. Glob Health Res Policy. 2020;5:1-3.

2. World Health Organization. Coronavirus disease 2019 (COVID-19) Situation Report [Internet]. 2020 [Cited 2020 Dec 8]. Available from: https://www.who.int/ emergencies/diseases/novel-coronavirus-2019/situation-reports

3. Cucinotta D, Vanelli M. WHO declares COVID-19 a pandemic. Acta Biomed. 2020;91:157-60.

4. Pan X, Ojcius DM, Gao T, Li Z, Pan C, Pan C. Lessons learned from the $2019-\mathrm{nCoV}$ epidemic on prevention of future infectious diseases. Microbes Infection. 2020;22:86-91.

5. Wong TY, Koh GC, Cheong SK, Lee HY, Fong YT, Sundram M, et al. Concerns, perceived impact and preparedness in an avian influenza pandemic--a comparative study between healthcare workers in primary and tertiary care. An Acad Med Singap. 2008;37:96-102.

6. Dubey S, Biswas P, Ghosh R, Chatterjee S, Dubey MJ, Chatterjee S, et al. Psychosocial impact of COVID-19. Diabetes Metab Syndr. 2020;14:779-88.

7. Nicola M, Alsafi Z, Sohrabi C, Kerwan A, Al-Jabir A, Iosifidis $\mathrm{C}$, et al. The socio-economic implications of the coronavirus pandemic (COVID-19): a review. Int J Surg. 2020;78:185-93.

8. Wong SCY, Kwong RTS, Wu TC, Chan JWM, Chu MY, Lee SY. Risk of nosocomial transmission of coronavirus disease 2019: an experience in a general ward setting in Hong Kong. J Hosp Infect. 2020;105:119-27.

9. Chaudhary FA, Ahmad B, Ahmad P, Khalid MD, Butt DQ, Khan SQ. Concerns, perceived impact, and preparedness of oral healthcare workers in their working environment during COVID-19 pandemic. J Occup Health. 2020;62:e12168.

10. Boyraz G, Legros DN. Coronavirus Disease (COVID-19) and Traumatic Stress: Probable Risk Factors and Correlates of Posttraumatic Stress Disorder. J Loss Trauma. 2020;25:503-22.

11. International Council of Nurses. ICN calls for data on healthcare worker infection rates and deaths [Internet]. 2020 [Cited 2020 Dec 8]. Available from: https://www. icn.ch/news/icn-calls-data-healthcare-worker-infection-rates-and-deaths.

12. Gan WH, Lim JW, David K. Preventing intra-hospital infection and transmission of COVID-19 in healthcare workers. Saf Health Work. 2020;11:241-3.

13. Channel News Asia. China says more than 3000 medical staff infected by COVID-19 [Internet]. 2020 [Cited 2020 Dec 8]. Available from: https://www.channel- newsasia.com/news/asia/covid19-china-says-medicalstaff-infected-by-coronavirus-12466054

14. Wong ELY, Wong SYS, Kung K, Cheung AWL, Gao TT, Griffiths S. Will the community nurse continue to function during H1N1 influenza pandemic: a cross-sectional study of Hong Kong community nurses? BMC Health Serv Res. 2010;10:107.

15. Shiao JSC, Koh D, Lo LH, Lim MK, Guo YL. Factors predicting nurses' consideration of leaving their job during the SARS outbreak. Nurs Ethics. 2007;14:5-17.

16. Baseer MA, Rahman G, Ali M. Infection control practices in dental school: A patient perspective from Saudi Arabia. Dent Res J. 2013;10:25-30.

17. Tada A, Watanabe M, Senpuku H. Factors influencing compliance with infection control practice in Japanese dentists. Int J Occup Environ Med. 2014;5:24-31.

18. Ibrahim NK, Alwafi HA, Sangoof SO, Turkistani AK, Alattas BM. Cross-infection and infection control in dentistry: Knowledge, attitude and practice of patients attended dental clinics in King Abdulaziz University Hospital, Jeddah, Saudi Arabia. J Infect Public Health. 2017;10:438-45.

19. Reichart PA, Gelderblom HR, Khongkhunthian P, Schmidt-Westhausen A. Ebola virus disease: any risk for oral and maxillo-facial surgery? An overview. Oral Maxillofac Surg. 2016;20:111-4.

20. Martin SD. Nurses' ability and willingness to work during pandemic flu. J Nurs Manag. 2011;19:98-108.

21. Damery S, Wilson S, Draper H, Gratus C, Greenfield $\mathrm{S}$, Ives J, et al. Will the NHS continue to function in an influenza pandemic? A survey of healthcare workers in the West Midlands, UK. BMC Public Health. 2009;9:142.

22. Ahmad S, Hussain S, Shah FS, Akhtar F. Urdu translation and validation of GAD-7: A screening and rating tool for anxiety symptoms in primary health care. J Pak Med Assoc. 2017;67:1536-40.

23. Tareen MS, McDowell C, Naqvi K, Bashir A, Keenan P, Rehman A, Farrell D. Evaluation of an Urdu version of the Impact of Event Scale-Revised. Int Psychiatry. 2012;9:20-2.

24. Chen CS, Cheng CP, Yen CF, Tang TC, Yang P, Yang RC. Validation of the Impact of Event Scale-Revised for adolescents experiencing the floods and mudslides. Kaohsiung J Med Sci. 2011;27:560-5.

25. Lu W, Wang H, Lin Y, Li L. Psychological status of medical workforce during the COVID-19 pandemic: A cross-sectional study. Psychiatry Res. 2020:112936.

26. Spoorthy MS, Pratapa SK, Mahant S. Mental health problems faced by healthcare workers due to the COVID-19 pandemic-A review. Asian J Psychiatr. 2020;51:102119. 
27. Tzeng HM, Yin CY. Nurses' fears and professional obligations concerning possible human-to-human avian flu. Nurs Ethics. 200;13:455-70.

28. Gershon RR, Magda LA, Qureshi KA, Riley HE, Scanlon E, Carney MT, et al. Factors associated with the ability and willingness of essential workers to report to duty during a pandemic. J Occup Environ Med. 2010;52:9951003.

29. Balicer RD, Omer SB, Barnett DJ, Everly GS. Local public health workers' perceptions toward responding to an influenza pandemic. BMC Public Health. 2006;6:99.

30. Ehrenstein BP, Hanses F, Salzberger B. Influenza pandemic and professional duty: family or patients first? A survey of hospital employees. BMC Public Health. 2006;6:311.

31. Zhang WR, Wang K, Yin L, Zhao WF, Xue Q, Peng M, et al. Mental health and psychosocial problems of medical health workers during the COVID-19 epidemic in China. Psychother Psychosom. 2020;89:242-50.

32. Xiao C. A novel approach of consultation on 2019 novel coronavirus (COVID-19)-related psychological and mental problems: structured letter therapy. Psychiatry Investig. 2020;17:175-6.

33. Kmietowicz Z. Rules on isolation rooms for suspected covid-19 cases in GP surgeries to be relaxed. BMJ. 2020;368:m707.

34. Ranney ML, Griffeth V, Jha AK. Critical supply shortages - the need for ventilators and personal protective equipment during the Covid-19 pandemic. N Engl J Med. 2020;382:e41.

35. Lai J, Ma S, Wang Y, Cai Z, Hu J, Wei N, et al. Factors associated with mental health outcomes among health care workers exposed to coronavirus disease 2019. JAMA Netw Open. 2020;3:e203976.

36. Tai DYH. SARS plague: duty of care or medical heroism? Ann Acad Med Singp. 2006;35:374-8.

37. Cai Q, Huang D, Ou P, Yu H, Zhu Z, Xia Z, et al. COVID-19 in a designated infectious diseases hospital outside Hubei Province, China. Allergy. 2020;75:1742-52.

38. Friedman LE, Gelaye B, Sanchez SE, Williams MA. Association of social support and antepartum depression among pregnant women. J Affect Disord. 2020;264:2015.

39. Jiang X, Deng L, Zhu Y, Ji H, Tao L, Liu L, et al. Psychological crisis intervention during the outbreak period of new coronavirus pneumonia from experience in Shanghai. Psychiatry Res. 2020:112903.

40. Swerdlow DL, Finelli L. Preparation for possible sustained transmission of 2019 novel coronavirus: lessons from previous epidemics. JAMA. 2020;323:1129-30.

41. Ahmadi H, Ebrahimi A, Ghorbani F. The impact of COVID-19 pandemic on dental practice in Iran: a questionnaire-based report. BMC Oral Health. 2020;20:354.

42. Schwendicke F, Krois J, Gomez J. Impact of SARSCoV2 (Covid-19) on dental practices: Economic analysis. J Dent. 2020;99:103387.

\section{Psihološki utjecaj pandemije COVID-19 na dentalne zdravstvene radnike i njihovu spremnost za rad tijekom ove pandemije}

Sažetak - Cilj ove studije bio je istražiti vezu između psihološkog statusa dentalnih zdravstvenih radnika (DZR) i spremnosti za liječenje pacijenta tijekom pandemije COVID-19. Ovo presječno istraživanje provedeno je na radnicima dentalne zdravstvene zaštite u deset različitih stomatoloških bolnica u Pakistanu od ožujka do srpnja 2020. Podaci o socijalno-demografskom statusu i spremnosti za javljanje na dužnost i liječenje pacijenata tijekom pandemije COVID-19 procijenjivani su pomoću samoocjenskog upitnika. Psihološki utjecaj pandemije COVID-19 procijenjen je korištenjem urdske verzije skale generaliziranog anksioznog poremećaja (GAD) i skale utjecaja događaja (IES). Za analizu su korišteni jednostavni i višestruki linearni regresijski testovi. Ukupno su 392 DZR-a sudjelovala u ovoj studiji, a 25\% ih je imalo umjerenu do ozbiljnu razinu anksioznosti, a samo 14\% posttraumatski stresni poremećaj. Oko 26\% DZR-a bilo je spremno raditi i liječiti pacijente tijekom pandemije COVID-19 i imali su niže rezultate anksioznosti i stresa. Veće razine anksioznosti i stresa bile su povezane sa sudionicima koji su stariji, ženskog spola, slobodni, oženjeni, koji su živjeli s obitelji i prijateljima. Prilagođeni koeficijenti GAD i IES rezultata bili su veći kod sudionika koji nisu bili voljni i sigurni raditi u odnosu na njihove kolege koji su to htjeli. DZR su zabrinuti i pod stresom zbog izbijanja COVID-19, a to utječe na percepciju trebaju li raditi i liječiti pacijente tijekom pandemije.

Ključne riječi: anksioznost; COVID-19; djelatnik dentalne zdravstvene zaštite; psihološki utjecaj; spremnost 
